\title{
STUDENTS' EXPECTATIONS OF FEEDBACK GIVEN ON DRAFT WRITING
}

\author{
Shena Lamb \\ Nelson Mandela Metropoliton University \\ Zach Simpson \\ University of Johannesburg
}

Academic writing is the primary means of assessing university students and feedback (oral or written responses) on writing can contribute significantly to student learning and success (Ferris, 2003; Hyland \& Hyland, 2006). This study explores students' expectations of feedback on draft writing. The research design was two-pronged. The initial quantitative aspect employed a questionnaire which students completed after receiving feedback from Writing Centre consultants who aim to give developmental feedback. A subsequent phase involved focus groups with volunteer students. This mixed methods design allowed for greater depth of understanding as the qualitative findings extended the quantitative results. The study concludes that students expect feedback to be understandable, encouraging and to focus on both positive and negative aspects of their writing. Importantly, students expect feedback to 'unpack' the conventions of academic literacy while still encouraging independence and originality.

\section{Keywords}

Feedback; academic writing; mixed methods; Writing Centres

\section{INTRODUCTION AND BACKGROUND}

In 2005, the Department of Education's Directorate on Higher Education Planning reported that, in 2000, 30 percent of South African students dropped out of their first year of study; a further 20 percent dropped out in their second or third year; and, on average, only 15 percent finished their degrees in the specified time (Cosser \& Letseka, 2010: 3). Directly linked to these low national graduation rates, is the low literacy level of high school learners entering tertiary education. Vithal (2009) emphasises that inadequate language proficiency of students emerging from the schooling system can prevent them from adequately benefiting from and contributing to higher education.

This concern regarding the preparedness of students entering tertiary education underpins this research study which takes place within the context of Writing Centres, where novice academic writers (mostly first- and second-year students) are assisted in their apprenticeship of writing and constructing knowledge. The study explores students' expectations of the feedback received from writing consultants at two Writing Centres in South Africa - one at 
the Nelson Mandela Metropolitan University (NMMU) and the other at the University of Johannesburg (UJ).

Both Writing Centres adopt a process-approach ${ }^{1}$ to writing and the pedagogy of the Centres is dependent on collaboration, peer learning and individualised assistance. This approach does not focus on errors and does not attempt to evaluate student writing in the sense of grading it. Instead, focused developmental feedback is given to students so that they can improve their own writing competence.

The primary aim of this research is to create a greater understanding between writing consultant and student by means of establishing a more authentic dialogue within the discourse of the student's draft. The problem statement that this study addresses, is: What are students' perceptions of feedback given by writing consultants on their draft writing?

To this end, a survey was conducted with a total of 84 students (42 students from each university) to ascertain students' attitudes towards the feedback they received from writing consultants on their draft writing. Focus group discussions, with two groups of three to four volunteer survey respondents, were also conducted at each university.

The results of this research could sharpen the practice of writing consultants by increasing their awareness of what works for students, as well as assisting in integrating the teaching of writing practices into university curricula. In the context of transformation and development, research of this nature recognises the role of writing in developing a nation of critical readers and thinkers.

\section{LITERATURE REVIEW}

In the last twenty years, feedback has moved from 'a narrow obsession with error correction ... to embrace a new range of issues ... [such as] student preferences and responses to feedback and the role of wider, societal, institutional ... factors' (Hyland \& Hyland, 2006: 96). ${ }^{2}$ For example, the framework that Coffin, Curry, Goodman, Hewings, Lillis and Swann (2003: 105) suggest for giving feedback lists a hierarchy in which content is more important than linguistic accuracy. Ferris (2003: 113) ${ }^{3}$ maintains that feedback comments can be directive or facilitative and in the form of statements or questions. She identifies eight ways of giving feedback (asking for information; giving direction by questioning, in a statement or in an imperative; giving information in a question or statement; giving a positive comment; and commenting on grammar or mechanics). Hyland and Hyland (2006: 86) provide only three ways of giving feedback - praise, criticism and suggestion - and propose a continuum between suggestion and criticism. They suggest that lecturers begin with what is ineffective in the writing and move toward a plan for improvement.

The most basic difference in feedback function is feedback giving a message and feedback correcting an error. A distinction is also made between 'global' (overall) feedback and 'local' feedback which occurs at specific points in the text. Global feedback looks at the structure, cohesion and signposting of the argument, as well as the tone of the writer's voice and reader positioning. It includes positive comments, identifies immediate concerns and links to the local comments. 
However, because feedback takes place in particular cultural and institutional settings (Hyland \& Hyland, 2006: 96), it is of primary importance that feedback, while addressing the implications of these settings, allows students to achieve their own goals (Lensmire, 2000: 14). Ferris (2003: 14) warns that students often make the suggested changes to comply rather than to develop their own thinking and Lensmire (2000: 14-17) stresses that feedback needs to develop students as critical thinkers. This is supported by Cuseo (2009) who defines critical thinking as: comprehension, application, analysis, synthesis, evaluation, deduction, induction, adduction, refutation, balanced thinking, multiple perspective-taking, causal reasoning, ethical reasoning and creative thinking. The challenge is therefore to give feedback that 'offer[s] students tasks of a different order of complexity ... by forcing students back ... to the point where they are shaping and restructuring their meaning' (Sommers, 2006: 154). Although this can be a slow process, Ferris emphasises that 'construct[ing] feedback carefully and thoughtfully can transform what may appear to be a tedious, thankless job into a creative, dynamic, rewarding process' (Ferris, 2003: 134).

Such an approach to giving feedback takes cognizance of Paxton's (2007) notion of interim literacies, where mastery of academic literacy conventions is seen as the outcome of university education rather than a prerequisite. Jacobs (2007) argues that it is unrealistic to expect students to have gained full control of the conventions of academic language upon entry into higher education. Instead, when students enter university, they begin a period of interim literacy during which they come to understand and gain control of these practices (Paxton, 2007). Their progression through interim literacy towards full academic literacy is promoted, inter alia, through effective delivery of feedback on students' draft writing.

To avoid a 'one size fits all' approach, Ferris (2003: 188) recommends a multiple draft process of peer feedback, lecturer-student consultation, written commentary and selfevaluation. She suggests not responding to every draft of every student, or to every issue, but to tailor responses to individual needs guided by assessment criteria and each student's writing. However, Ferris admits that giving clear and helpful feedback is challenging and underlines that constructive feedback addresses two primary questions: does the student have the background to understand the feedback, and will the comment improve the essay?

Where multiple drafts are submitted, Ferris argues for the prioritisation of issues - first, idea development, then argument coherence and, finally, editing, but stresses that the process is recursive. Ferris contends that feedback strategies need to be explained in advance and that students need to be held accountable for using feedback. Ferris also warns against the two most common errors: (1) 'taking over' or, in the words of Brannon and Knoblauch (1982), 'appropriating' students' writing and (2) not giving text-specific feedback.

There is an ongoing debate as to the extent to which feedback comments should be directive. Students appear to use direct feedback more consistently but indirect feedback seems to yield greater long-term improvement (Hyland \& Hyland, 2006: 85). Lecturers' instructions and class activities such as peer feedback also need to be taken into account. For example, teacher feedback usually has a greater impact on revision than peer response (Ferris, 2003: 29). However, Ferris believes that peer feedback can be very valuable to student writers, especially when they know from the start that they will be sharing their writing and when the process is carefully explained and managed (ibid: 175-176). 


\section{METHODOLOGY}

This study seeks to address the following question: What are students' expectations of the feedback they receive from writing consultants on their draft writing? To this end, a twopronged methodology was followed. In the first phase, a questionnaire was designed which aimed to ascertain students' attitudes and feelings about the feedback given to them. The questionnaire was completed by 42 students at each university (a total of 84 respondents) and consisted of eight questions, the first of which established whether this was the student's first visit to the Writing Centre, giving a Yes/No response option. Questions 2 to 3 made use of the Likert scale (1932: 1-55) in which a score of 1 represented strong disagreement and a score of 5 represented strong agreement (see Appendix A for the survey instrument). In analysing the questionnaire data, average respondent scores of below 2.5 were taken to represent overall disagreement with the given statement and scores above 3.5 were considered to represent overall agreement. Scores between 2.5 and 3.5 were taken to represent general ambivalence towards the statement. Questions 5, 6 and 7 were open-ended questions concerning students' experience of the Writing Centre and Question 8 asked for their voluntary participation in a subsequent focus group.

The second phase of the study consisted of focus group interviews conducted with six students from each institution. The aim of the focus group discussions was to clarify and gain greater insight into the students' responses to the questionnaires. The following table provides information about the students who participated in these focus group interviews:

Table 1: Focus group participants

\begin{tabular}{|c|c|c|c|c|c|}
\hline Focus group & Student & Gender & $\begin{array}{l}\text { Mother } \\
\text { tongue }\end{array}$ & $\begin{array}{l}\text { Year of } \\
\text { study }\end{array}$ & Degree \\
\hline \multirow{4}{*}{$\begin{array}{l}\text { NMMU } \\
\text { Focus Group } \\
1\end{array}$} & $\mathrm{~A}$ & Female & isiXhosa & Third & Logistics \\
\hline & $\mathrm{B}$ & Female & isiXhosa & First & $\begin{array}{l}\text { Human } \\
\text { Management }\end{array}$ \\
\hline & $\mathrm{C}$ & Female & isiXhosa & First & $\begin{array}{ll}\text { Human } & \text { Resource } \\
\text { Management } & \\
\end{array}$ \\
\hline & $\mathrm{D}$ & Female & isiXhosa & Second & Public Management \\
\hline \multirow{2}{*}{$\begin{array}{l}\text { NMMU } \\
\text { Focus Group } \\
2\end{array}$} & $\mathrm{E}$ & Female & Afrikaans & Second & $\begin{array}{ll}\text { Human } & \text { Resource } \\
\text { Management } & \\
\end{array}$ \\
\hline & $\mathrm{F}$ & Female & Chinese & Fourth & Business Management \\
\hline \multirow{3}{*}{$\begin{array}{l}\text { UJ Focus } \\
\text { Group } 1\end{array}$} & $\mathrm{G}$ & Male & Xitsonga & Third & Education \\
\hline & $\mathrm{H}$ & Female & Xitsonga & First & Education \\
\hline & $\mathbf{J}$ & Female & Xitsonga & First & Education \\
\hline \multirow{3}{*}{$\begin{array}{l}\text { UJ Focus } \\
\text { Group } 2\end{array}$} & $\mathrm{~K}$ & Female & English & First & Marketing Communication \\
\hline & $\mathrm{L}$ & Female & seTswana & Second & Journalism \\
\hline & $\mathrm{M}$ & Female & English & Third & Development Studies \\
\hline
\end{tabular}

In the focus groups, the participants were asked to consider the following questions:

- What makes writing good?

- What makes writing bad?

- What helps writing the most?

- What helps writing the least?

- What do you usually do when revising your writing?

- What encourages you to revise your writing? 
- What can the NMMU/UJ Writing Centre do to improve your writing?

\section{RESULTS AND DISCUSSION}

As mentioned above, the questionnaire that comprised the first phase of the study consisted of five central questions. Question 2 asked students to identify the main focus of their consultation and to what extent they were helped by the consultant's feedback. In response, students at both NMMU and UJ identified essay structure as the area in which they had received the most assistance and mechanics as the area in which they had received the least assistance. This may suggest that students require greater assistance with higher order concerns such as essay structure and validates Writing Centres' focus on prioritising these concerns.

Question 3 concerned students' reactions to comments from the writing consultants. Here, the students expressed general agreement (average scores over 3.5) with the positive statements and disagreement (average scores below 2.5) with the negative statements (Table 2, below, illustrates these results). An exception to this was the statement, 'I understood some of the consultant's feedback, but a lot of it just went right over my head'. At both NMMU (2.46) and UJ (2.69), the students expressed a higher degree of ambivalence than disagreement with this statement, with average scores between 2.5 and 3.5.

Table 2: Summary of responses to question 3

\begin{tabular}{|l|l|l|}
\hline Q3: The consultant ... & $\begin{array}{l}\text { NMMU } \\
\text { sample }\end{array}$ & $\begin{array}{l}\text { UJ } \\
\text { sample }\end{array}$ \\
\hline Q3.1 identified problems I had not thought about & 4.37 & 4.33 \\
\hline $\begin{array}{l}\text { Q3.2 took time to explain each point / made sure that I } \\
\text { understood }\end{array}$ & 4.15 & 4.29 \\
\hline Q3.3 gave me feedback that went over my head & 2.46 & 2.69 \\
\hline Q3.4 just repeated the same things over and over & 2.12 & 2.14 \\
\hline Q3.5 went very quickly through my work & 2.39 & 2.36 \\
\hline Q3.6 only dealt with some aspects & 1.85 & 2.07 \\
\hline
\end{tabular}

Question 4 explored students' feelings after their experience of having received feedback from the writing consultants. Table 3, below, illustrates these results. Once again, the students generally expressed agreement with the positive statements and disagreement with the negative statements. However, this was not the case with the statement, 'Although what the consultant said made sense, I still couldn't easily revise my writing on my own'. Here again, students were more ambivalent, with mean scores of 2.46 (NMMU) and 2.62 (UJ). The results obtained for questions 3 and 4 suggest that more needs to be done to ensure that students understand and can apply the feedback they receive on their writing.

Question 5, the first of the two open-ended questions, asked students to describe their experience at the Writing Centre. At NMMU only one student had a negative experience (concerning contradictions between the consultant and the lecturer and the methods employed in the classroom) although three students (7\%) felt that the comments, while helpful, 'didn't always deal with what I didn't understand'. At UJ, two students described their experience in 
negative terms: one complained about needing more constructive criticism and the other described the experience as 'overwhelming'. The rest of the comments at both institutions were positive.

Table 3: Summary of responses to question 4

\begin{tabular}{|l|l|l|}
\hline Q4: Attitudes after receiving feedback & $\begin{array}{l}\text { NMMU } \\
\text { sample }\end{array}$ & $\begin{array}{l}\text { UJ } \\
\text { sample }\end{array}$ \\
\hline Q4.1 My specific questions were addressed & 4.00 & 4.33 \\
\hline Q4.2 I felt I could revise my writing easily & 3.93 & 4.19 \\
\hline $\begin{array}{l}\text { Q4.3 I'll get assistance from the Writing Centre } \\
\text { again next time }\end{array}$ & 3.29 & 3.50 \\
\hline Q4.4 I feel I can't revise on my own & 2.46 & 2.62 \\
\hline Q4.5 I felt as confused as ever & 1.83 & 1.57 \\
\hline
\end{tabular}

Finally, Question 6, also an open-ended question, asked students to specify the improvements they would make in their future writing. The most common responses amongst NMMU students pertained to the conventions of academic writing, with 24 percent saying they would 'follow the requirements regarding structure and paragraph links as well as technical requirements' and 24 percent 'paying closer attention to referencing'. In addition, 15 percent indicated they would 'research more thoroughly'. At UJ, the students' responses were noticeably less specific. Less than one-third of the UJ students indicated they would attend to academic writing conventions such as structure, logic, paragraphing, coherence and argument. Many students responded with statements such as 'I will attend to what the consultant spoke about' (19\%). In these responses, the students either were not able or chose not to clearly articulate in what specific ways they needed to improve their writing. This raises questions as to whether or not the students' experiences in the Writing Centre will in fact lead to developed writing practice.

The results of questions 5 and 6 suggest that, while students are concerned with the consistency, volume and clarity of feedback received, most of them are satisfied with their experience of having visited the Writing Centre. The fact that the students' experiences are positive creates a positive affiliation with the Writing Centre, especially as regards their selfconfidence and motivation. However, of concern is the finding that, although students may feel positive about the feedback they have received on their draft writing, they are not always fully able to enact the suggested changes on their own. This is a significant finding for the work of Writing Centres and suggests that more attention needs to be paid to making Writing Centre feedback understandable and to ensuring that students are able to implement the suggested improvements in their future writing. This may require greater focus on addressing feedback at the level of the student and allowing student needs to dictate the feedback offered.

In addressing this issue more closely in the focus groups, most students felt 'outside' the conventions of essayist literacy and valued feedback which could clarify these conventions. Student A admits '... when you told us the [what], why and the how ... those three questions really ... guided me to write my assignment's introduction' and Student B felt that when 'you don't understand the topic ... you will come up with ideas that won't relate to what is ... what is given'. These comments suggest that, until students feel comfortable or are familiar with academic conventions, they cannot easily experience writing as a 'meaning-making activity' (Kamler \& Thomson, 2006: 4) which can affect their emerging writer identity. 
A key problem for these students was including other voices in their texts. Student A admits: 'what I had problems with the most was ... referencing' and Student B elaborates, 'this [referencing] kills you ... because ... by the time you put it down you could see that it's similar to what the author has written ... then you can take it to the lecturer but he could see that you've got plagiarism [sic] but you've not plagiarised ... you paraphrased on your own' (emphasis added). Student B's incomplete citation is what Rebecca Moore Howard calls 'patch writing': 'copying from a source text and deleting some words, altering grammatical structures or plugging in one-for-one synonym-substitutes' (Howard, 1999 in SutherlandSmith, 2008: 25-26). Howard claims that patch writing is not plagiarism but 'a strategy in the ongoing process of learning to write in a new academic discourse' and that students accused of plagiarism often only need to be shown how to acknowledge the source of their patch writing. This is similar to Paxton's (2007: 46) idea of the 'interim literacy' of most first-year students.

Another problem area is the conflation of revising with correcting mistakes. Student $\mathrm{L}$ sees revising as learning 'where you went wrong' and Student $\mathrm{N}$ suggests that there is a 'right way to revise my essay'. Such beliefs represent what Johns (1997) calls a traditional view of literacy in which language is seen as rule-governed and effective writing equates with 'good' grammar. Sutherland-Smith (2008: 298) suggests that this view of literacy is held by lecturers who adopt a 'transmissive' approach to teaching where 'students learn that their role is to regurgitate information uncritically' and translates into feedback that tells students how to correct their work. Lensmire (2000: 45) argues that 'if you're looking for spelling, punctuation or grammar errors, you will not follow the meaning. But if you are looking for the meaning, you will find it' and that students need to be encouraged to interrogate their ideas. Ferris (2003: 30) maintains that students who receive meaning-based feedback show improved understanding of content in the long term.

Linked to the students' difficulties is the difference between school-based literacy and academic literacy. Student K mentions 'this whole gap between what's expected of you in your last year of high school and ... in your first year after high school' and Students L and A ask for 'a specific guideline across all the departments on how we should write' or 'an old assignment or something. Showing is more helpful ... if you just [say] this is what you should do ... and you don't explain ... sometimes I can read but I won't understand ... I need someone to ...really, really, explain'. Beaumont, O'Doherty and Shannon (2008) ${ }^{4}$ investigated the impact of prior assessment experience on first-year students' expectations of feedback, finding that schools place '...considerable emphasis on preparatory guidance and continual support through the writing stage to the submission of a coursework assignment' and conclude that experiences of feedback 'as a dialogic and formative process [is] the benchmark by which all feedback at university is judged' (Beaumont et al., 2008: 16).

As part of such dialogue, positive feedback helps students engage more with their writing. Students E and F say that 'good comments ... motivate you to do better' and 'if it's just ... change this, change that, you feel frustrated, you don't want to do it ... but if ... there's a good comment like 'well done for this', that really makes you want to work more on it'. Similarly, Student J speaks of gaining 'courage', Student G speaks of 'assurance', and Student $\mathrm{H}$ of 'confidence'. As mentioned, the results of the questionnaire showed that students, on the whole, had positive feelings regarding feedback received from their Writing Centre. Lillis (2001: 6) stresses that students bring many cultural and social experiences to their academic writing and positive feedback helps validate these experiences by influencing personal motivation and developing an authentic voice. 
Asked whether they preferred directive or non-directive comments, most students wanted both and their comments validated the recommendations that Ferris (2003: 158) gives of using directive comments for superficial concerns (Student F: 'I like to know the rule') and non-directive comments when meaning is at stake (Student E: 'I don't only consider one thing') although Ferris concludes that effective feedback uses a combination of both.

Some students felt strongly about the acknowledgement of their ideas. For instance, Student E said she did not implement any comment that changed what she wanted to say: '... sometimes when I feel it is changing my meaning, I leave it') and Student L mentions conflict in the writing consultation when her concerns were ignored: 'I don't think we even understood each other, because I'm trying to tell him that, dude, how can I narrow this down to 500 [words], he's telling me about sentences, I'm like, no, tell me how you would do it, so that I at least have a frame'.

These comments reinforce Angelil-Carter's (2000: 122) argument that not acknowledging students' background knowledge may alienate them and Lensmire's (2000: 45) contention that writing pedagogy should allow students to maintain control over their own writing. Lillis (2001) regards this as the difference between traditional feedback and 'talkback' which focuses on the text-in-process and predominantly uses questioning.

The conclusive consideration might be the difference between surface and deep learning. Biggs (2003) suggests that students who adopt a surface approach to learning are unable to properly engage with content, whereas students who adopt a deep approach to learning are able to work at a conceptual level. As Kamler (2001: 85) insists, 'why and how students write is not separable from their lives'.

\section{CONCLUSIONS AND RECOMMENDATIONS}

Students generally have a positive experience of receiving feedback from Writing Centres (at the institutions involved) as they gain both motivation and confidence from receiving constructive criticism which encourages them to engage more deeply with their texts. Writing Centre feedback is thus of value in developing students as critical thinkers. However, students do not always understand feedback given and are not always able to implement the suggested changes on their own.

During the focus group discussions, students offered various reasons for not understanding feedback: confusion when explanations did not contain sufficient detail; frustration when unfamiliar conventions were assumed and indignation when accused of plagiarism despite efforts to apply their understanding of the rules. These reactions suggest that students expect feedback to make academic writing conventions explicit by giving detailed explanations which do not assume too much prior knowledge. This expectation is reflected in the students' frustration with the difference between school and university literacy and points to an important recommendation: feedback should begin with students' previous experience of assessment which invariably is the more scaffolded approach they receive at school. Interestingly, this is also recommended by Beaumont et al. (2008: 16) who stress the importance of developing an assessment curriculum which, as its starting point, uses students' prior experience of assessment and calls for 'formative activities that scaffold increasing selfdirection in learning by developing a student's ability to self-assess'. 
Aligned to this recommendation is students' sometimes seemingly unconscious expectation that feedback - to some degree - reinforces their sense of themselves as people and as developing writers. What emerged repeatedly from the focus groups is that what most helps students to develop as novice writers of a new discourse is dialogue, whether with Writing Centre consultants, lecturers or peers. Implicit in many student comments was the desire for more opportunities to discuss all aspects of their writing - from initial guidance in the writing task and explanation of criteria (especially with exemplars) to continuous feedback during the writing process. Highlighting this need for a scaffolded approach is the preoccupation of most students with error correction and linguistic accuracy as opposed to concern with meaningmaking: once students feel comfortable with the conventions of academic writing, they are more likely to understand their role in the meaning-making process.

\section{NOTES}

${ }^{1}$ The process approach allows students to complete multiple drafts, encourages substantive revision and gives students feedback while they are in the process of writing rather than at the end of that process (Ferris, 2003:1).

${ }^{2}$ In their state-of-the-art article on giving feedback to second language students' writing, Hyland and Hyland give a wide-ranging summary of recent research on giving feedback on L2 students' writing and conclude that future research needs to address, inter alia, how peer feedback and oral conferences can help students develop independent writing skills (Hyland \& Hyland, 2006:96).

${ }^{3}$ In her analysis of error correction research, Ferris examines 16 diverse studies conducted from 1976 to 2001 in different parts of the world, with differing sample sizes and research questions. She concludes that many questions in error correction of student writing have not been adequately researched yet (Ferris, 2003:67).

${ }^{4}$ This research project was undertaken in three phases: the first strand explored student perceptions and experience of feedback (and university expectations) at three schools and three colleges by conducting focus groups at each with Year 13 students. Teachers were also interviewed. The majority of pupils were studying Alevels and all intended to enter higher education. The second strand, which involved 108 students and 10 staff, investigated student perceptions of feedback quality during their first-year university experience and was composed of student focus groups at three points in the year and tutor interviews. Finally, a cross-institutional perspective was obtained by repeating student focus groups at two other universities to compare results. A questionnaire, completed by 176 students, was also used to check the validity of the findings (Beaumont, O’Doherty \& Shannon, 2008: 6).

\section{REFERENCES}

ANGELIL-CARTER, S. 2000. Stolen language? Plagiarism in writing. Harlow, England: Pearson.

BEAUMONT, C, M O'DOHERTY \& L SHANNON. 2008. Staff and student perceptions of feedback quality in the context of widening participation [Online]. Available: www.heacademy.ac.uk/assets/York/documents/ourwork/research/Beaumont_Final_Rep ort.pdf [2010, 9 February].

BIGGS, J. 2003. Teaching for quality learning at university. ( $2^{\text {nd }}$ edition). Buckingham: Open University Press.

BRANNON, L \& CH KNOBLAUCH. 1982. On students' rights to their own texts: A model of teacher response. College Composition and Communication, 33(2):157-166.

COFFIN, C, MJ CURRY, S GOODMAN, A HEWINGS, TM LILLIS \& J SWANN. 2003. Teaching academic writing. Cambridge: Cambridge University Press. 
COSSER, M \& M LETSEKA. 2010. 'Introduction'. In: Letseka, M, M Cosser, M Breier \& M Visser. 2010. (Eds). Student retention and graduate destination: Higher education and labour market access and success [Online]. Available: http://www.hsrcpress.ac.za/product.php?productid=2272 [2010, 15 February, 2010].

CUSEO, J. 2009. Critical and creative thinking in the first year of college and beyond. Paper presented at the Symposium on Promoting First-year Student Success in College and Beyond in October, 2009. Oak Brook, IL.

FERRIS, D. 2003. Response to student writing: Implications for second language students. Mahwah, NJ: Lawrence Erlbaum.

HYLAND, K \& F HYLAND. 2006. Feedback on second language students' writing. Language Teaching, 39:83-101.

JACOBS, C. 2007. Mainstreaming academic literacy teaching: Implications for how academic development understands its work in higher education. South African Journal of Higher Education, 21(7):870-881.

JOHNS, AM. 1997. Text, role, and context: Developing academic literacies. Cambridge: Cambridge University Press.

KAMLER, B. 2001. Relocating the personal: A critical writing pedagogy. Albany: State University of New York Press.

KAMLER, B \& P THOMSON. 2006. Helping doctoral students write. New York: Routledge.

LENSMIRE, TJ. 2000. Powerful writing, responsible teaching. New York: Teachers College Press.

LIKERT, RA. 1932. A technique for the measurement of attitudes. Archives of Psychology, 22(140):1-55.

LILLIS, TM. 2001. Student writing: Access, regulation, desire. New York: Routledge.

PAXTON, M. 2007. Students' interim literacies as a dynamic resource for teaching and transformation. Southern African Linguistics and Applied Language Studies, 25:45-55.

SOMMERS, N. 2006. Across the drafts. College Composition and Communication, 58(2), December:248-256.

SUTHERLAND-SMITH, W. 2008. Plagiarism, the internet and student learning: Improving academic integrity. New York and London: Routledge, Taylor \& Francis Group.

VITHAL, R. 2009. Keynote address. $3^{\text {rd }}$ Annual teaching and Learning conference, September 2009, Durban. Durban: University of KwaZulu-Natal

\section{BIOGRAPHICAL NOTE}

Since 2005 Shena Lamb has been coordinating one of the writing centres at the Nelson Mandela Metropolitan University in Port Elizabeth. She worked as an editor for the United Nations in Rome for seven years before cofounding a sustainable development project in Spain where she lived for 12 years. She is currently doing an MA in conflict management.

E-mail address: shena.lamb@nmmu.ac.za

Zach Simpson coordinated the University of Johannesburg's Writing Centre from 2007 to 2009 . He has since left the Centre to pursue writing-intensive teaching in the Faculty of Engineering and the Built Environment. He holds an MA degree in Applied English Language Studies from the University of the Witwatersrand. E-mail address: zsimpson@uj.ac.za 


\section{APPENDIX - STUDENT QUESTIONNAIRE}

\begin{tabular}{|c|c|c|c|c|c|c|}
\hline 1 & Was this the first time you visited the Writing Centre? & \multicolumn{2}{|c|}{ Yes } & \multicolumn{3}{|c|}{ No } \\
\hline 2 & To what extent did the consultant help you to ... & 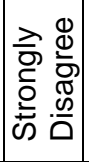 & 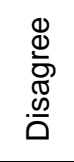 & 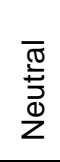 & $\frac{\Phi}{\frac{8}{4}}$ & 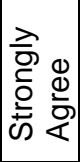 \\
\hline 2.1 & achieve the purpose of your essay & 1 & 2 & 3 & 4 & 5 \\
\hline 2.2 & arrange your ideas in a logical order & 1 & 2 & 3 & 4 & 5 \\
\hline 2.3 & $\begin{array}{l}\text { structure your essay (introduction, other } \\
\text { paragraphs/section }\end{array}$ & 1 & 2 & 3 & 4 & 5 \\
\hline 2.4 & write in a formal academic way & 1 & 2 & 3 & 4 & 5 \\
\hline 2.5 & check spelling, grammar and punctuation & 1 & 2 & 3 & 4 & 5 \\
\hline 2.6 & Other, please specify: & & & & 4 & 5 \\
\hline 3 & $\begin{array}{l}\text { To what extent do the following statements describe } \\
\text { your feelings during your visit to the Writing Centre? }\end{array}$ & 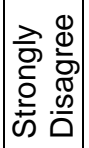 & 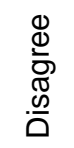 & 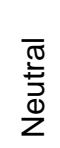 & 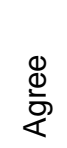 & 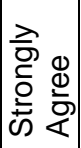 \\
\hline 3.1 & $\begin{array}{l}\text { I understood some of the consultants' feedback, but a lot } \\
\text { of it just went right over my head }\end{array}$ & 1 & 2 & 3 & 4 & 5 \\
\hline 3.2 & $\begin{array}{l}\text { The consultant really took time to explain each point and } \\
\text { made sure that I understood how to revise my } \\
\text { assignment }\end{array}$ & 1 & 2 & 3 & 4 & 5 \\
\hline 3.3 & $\begin{array}{l}\text { The consultant just repeated the same things over and } \\
\text { over }\end{array}$ & 1 & 2 & 3 & 4 & 5 \\
\hline 3.4 & $\begin{array}{l}\text { The consultant went through my assignment very } \\
\text { quickly }\end{array}$ & 1 & 2 & 3 & 4 & 5 \\
\hline 3.5 & $\begin{array}{l}\text { The consultant was able to identify problems in my } \\
\text { assignment that I had not thought about before }\end{array}$ & 1 & 2 & 3 & 4 & 5 \\
\hline 3.6 & $\begin{array}{l}\text { The consultant only dealt with some aspects of my } \\
\text { assignment and ignored others }\end{array}$ & 1 & 2 & 3 & 4 & 5 \\
\hline 4 & $\begin{array}{l}\text { To what extent do the following statements describe } \\
\text { your feelings after your visit to the Writing Centre? }\end{array}$ & 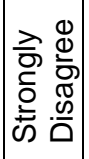 & 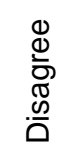 & 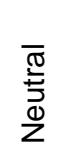 & 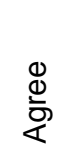 & 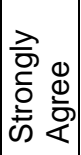 \\
\hline 4.1 & I feel as confused as ever & 1 & 2 & 3 & 4 & 5 \\
\hline 4.2 & I feel like I can go and revise my paper, easily & 1 & 2 & 3 & 4 & 5 \\
\hline 4.3 & $\begin{array}{l}\text { Although it makes sense when the consultant says it in } \\
\text { the Writing Centre, often I can't quite figure it out when } \\
\text { I'm at home writing }\end{array}$ & 1 & 2 & 3 & 4 & 5 \\
\hline 4.4 & $\begin{array}{l}\text { I feel like I am going to have to come back to the Writing } \\
\text { Centre to get more assistance }\end{array}$ & 1 & 2 & 3 & 4 & 5 \\
\hline 4.5 & $\begin{array}{l}\text { I came to the Writing Centre with specific } \\
\text { questions/problems and these were addressed }\end{array}$ & 1 & 2 & 3 & 4 & 5 \\
\hline & & & & & & \\
\hline
\end{tabular}




\begin{tabular}{|c|c|c|c|}
\hline & $\begin{array}{l}\text { mplete the following sentence in as much detail as possib } \\
\text { ing feedback from the writing consultant about my written }\end{array}$ & $\begin{array}{l}\text { e: M } \\
\text { vork }\end{array}$ & erience of \\
\hline 6. & $\begin{array}{l}\text { Complete the following sentence in as much detail as } \\
\text { my assignment, I will need to ... }\end{array}$ & ossib & improve \\
\hline & $\begin{array}{l}\text { Would you be prepared to allow the Writing Centre to } \\
\text { see the final draft of the assignment that you received } \\
\text { feedback on today? }\end{array}$ & Yes & No \\
\hline & $\begin{array}{l}\text { Would you be willing to participate in a focus group } \\
\text { interview? (In a focus group interview, we get a group of } \\
\text { students together to talk about an issue - in this case, } \\
\text { your experience of receiving feedback in the Writing } \\
\text { Centre. The focus group interview would not take longer } \\
\text { than } 60 \text { minutes and would be arranged for a time that } \\
\text { suits you.) }\end{array}$ & Yes & No \\
\hline & If you answered 'Yes' to questions 7 and/or 8, please sup & ly th & wing: \\
\hline & Your name: & & \\
\hline & Your cell number: & & \\
\hline
\end{tabular}

